\title{
The Effect of Maternal Education and Antenatal Care on Basic Immunization Completeness in Children aged 12-23 Months in Asian and African: Meta-Analysis
}

\author{
Farida $^{1)}$, Vitri Widyaningsih ${ }^{2}$, Bhisma Murti') \\ 1)Masters Program in Public Health, Universitas Sebelas Maret \\ 2)Faculty of Medicine, Universitas Sebelas Maret
}

\section{ABSTRACT}

Background: Immunization is a process that makes a person immune or immune to infectious diseases, usually by administering vaccines. A child is said to have received complete basic immunization if he has received one BCG immunization, three DPT-HB-Hib immunizations, four polio immunizations, and one measles immunization. This study aims to estimate the effect of maternal education and antenatal care on the provision of complete basic immunization for children aged 12-23 months in Asia and Africa by means of a meta-analysis.

Subjects and Method: Meta-analyzes were performed by searching articles from the PubMed, SpringerLink, Science Direct, and Google Scholar databases. The keywords used are "immunization coverage" OR "vaccination coverage" OR "complete immunization" OR "complete vaccination" OR "full immunization" OR "full vaccination" AND children OR "child immunization" OR "child immunization coverage" AND "maternal education ". The inclusion criteria in this study were full text articles, published in 2012-2020, using English, cross-sectional study design, the final results of the study using the adjusted odd ratio (aOR), and the study sample was children aged 12-23 months in Asia and Africa. Article analysis was performed using RevMan 5.3 software.

Results: There were eleven articles analyzed in total. The results showed maternal education and antenatal care could improve the provision of complete basic immunization to children aged 12-23 months in Asia and Africa, maternal education $(\mathrm{aOR}=1.52 ; 95 \% \mathrm{CI}=1.06$ to $2.18 ; \mathrm{p}=$ 0.020), $\mathrm{I}^{2}=89 \%$ and care antenatal $(\mathrm{aOR}=$ 2.62; 95\% CI=1.84-3.72; $\mathrm{p}=0.002), \mathrm{I}^{2}=69 \%$.

Conclusion: Maternal education and antenatal care influence the provision of complete basic immunization to children aged 12-23 months in Asia and Africa.

Keywords: Maternal education, antenatal care, complete basic immunization, children 12-23 months

\section{Correspondence: \\ Farida. Masters Program in Public Health, Universitas Sebelas Maret. Jl. Ir. Sutami 36A, Surakarta 57126, Central Java. Email: farida- riza9232@gmail.com. Mobile: 085654415292.}

Cite this as:

Farida, Widyaningsih V, Murti B (2020). The Effect of Maternal Education and Antenatal Care on Basic Immunization Completeness in Children aged 12-23 Months in Asian and African: Meta-Analysis. J Matern Child Health. 05(06):614-628. https://doi.org/10.26911/thejmch.2020.05.06.02.

(c) (†) (-) Journal of Maternal and Child Health is licensed under a Creative Commons Attribution-NonCommercial-ShareAlike 4.o International License.

\section{BACKGROUND}

The improvement of the quality of human life in a country has been agreed internationally in the Sustainable Development Goals (SDG's) as a continuation of the Millennium Development Goals (MDGs). One of the SDG's targets by 2030 is to end preventable deaths of newborns and children under five, with each country aiming to reduce neonatal mortality to at least less than 12 per 1000 births and under-five mortality to as low as 25 per 1000 births (WHO, 2020e). 
The World Health Organization (WHO) launched a global expansion program on immunization (EPI) in 1974 to control and reduce vaccination-preventable diseases and deaths in children worldwide. For children under one year of age, the program recommends immunization at the state level of $90 \%$ and at least $80 \%$ within a district or equivalent administrative unit (Feldstein et al., 2017; Holipah et al., 2018; Lakew et al., 2015; Nozaki et al., 2019). The EPI launched at that time recommended the use of vaccines to protect against six diseases: tuberculosis (BCG), diphtheria, tetanus, pertussis (DTP vaccine), measles and poliomyelitis (WHO, 2020d). Thanks to the progress made by countries, current immunization is one of the safest, most cost-effective ways to prevent someone from contracting infectious diseases, prevent death and improve life that is given routinely from infancy (Adenike et al., 2017; Efendi et al., 2019; Holipah et al., 2018; WHO, 2020c).

Immunization programs now routinely reach more than $80 \%$ of children under one year of age (WHO, 2020b). Routine immunization is currently a key component of primary health care services in several countries (WHO, 2019a). Improving the performance of the national immunization program is needed to achieve and maintain high immunization coverage to increase protection from diseases that can be prevented by immunization for all people (Feldstein et al., 2017).

According to WHO, around 1.5 million children in the world die each year because of diseases that can be prevented by immunization (Adedire et al., 2016; Mbengue et al., 2017). A quarter of all deaths among children under five in 2017 came from pneumonia, diarrhea and measles. The majority of these deaths can be prevented through vaccination (UNI-
CEF, 2020). In 2018, there were approximately 19.4 million children in the world who did not receive complete immunization and some even did not get immunization at all. Of the 19.4 million children worldwide who did not receive 3 doses of DPT during the first year of life, 11.8 million (61\%) live in 10 countries: Nigeria (18\%), India (16\%), Pakistan (7\%), Indonesia (6\%), Ethiopia (4\%), the Democratic Republic of Go-ngo (3\%), Iraq (3\%), Angola (2\%), Brazil, (1\%) and South Africa (1\%) (Feldstein et al. , 2017).

More than half of all incompletely vaccinated children live in Nigeria, Pakistan, Indonesia and Ethiopia (WHO, 2019a). In fact, to get herd immunity, it requires high immunization coverage (at least 95\%) and evenly. DPT3 immunization coverage in Nigeria (57\%), India (89\%), Indonesia (79\%), and Ethiopia (72\%) (WHO, 2020a). Meanwhile, measles coverage in India (80\%), Indonesia (67\%), Nigeria (48\%), Pakistan (67\%), Senegal (63\%) (WHO, 2020c).

The importance of maternal education in children's health is universally recognized. Children of educated mothers, even mothers with only primary schooling are more likely to survive than children of uneducated mothers (WHO, 2020e). Previous study has theorized that maternal education, particularly literacy, improves cognitive and communication skills leading to healthier lifestyle choices leading to lower under-five mortality (Forshaw et al., 2017). Children of highly educated mothers are more likely to be fully immunized than mothers with low education (Holipah et al., 2018). A woman with a higher educational background is more likely to realize the importance of immunization.

Previous studies have reported that vaccination decision making begins during pregnancy and that complete immunization 
coverage is associated with various indices of maternal health service utilization, such as the presence of antenatal care (Nozaki et al., 2019). Noh et al., (2018) found that the number of 4 ANC visits was significantly more likely for children to be fully immunized. This is in line with Efendi et al., (2019), which states that mothers who attend antenatal care are less than 4 times less likely to complete basic immunization for their children compared to mothers who take antenatal care more than 4 times. In other words, those who attended the minimum standard of visits received positive benefits or completed immunization.

\section{SUBJECTS AND METHOD}

\section{Study Design}

This was meta-analysis and systematic review by collecting articles from PubMed, Google Schoolar, Springer Link, and Science Direct databases.

\section{Inclusion Criteria}

The inclusion criteria were full text articles, published in 2012-2020, using English, cross-sectional study design, reporting adjusted odd ratio (aOR), and the study sample was children aged 12-23 months in Asia and Africa.

\section{Exclusion Criteria}

The exclusion criteria were articles that had been meta-analysis and duplicated articles.

\section{Operational Definition of Variables} Complete basic immunization is a child who receives 1 dose of $B C G$ vaccine, 3 doses of Pentavalent vaccine (which contains five antigens against diphtheria, tetanus, pertussis, hepatitis B and haemophilus type b, 3 doses of polio vaccine (not including doses given immediately after birth) and 1 dose of measles vaccine.

\section{Data Analysis}

Data analysis in this study was carried out using RevMan 5.3 and the analysis included in this study was carried out by random effects analysis.

\section{RESULTS}

Key words used include: "immunization coverage" OR "vaccination coverage" OR "complete immunization" OR "complete vaccination" OR "full immunization" OR "full vaccination" AND children OR "child immunization" OR "child immunization coverage" AND "Maternal education". The article review process can be seen in the search flow as follows:

Removes duplicate data $(\mathrm{n}=331)$

Published articles $(\mathrm{n}=1259)$

Irrelevant title $=873$

Not cross sectional $=288$

Article not in English $=3$

Article not full text $=95$

Complete article issued with reasons $(\mathrm{n}=225)$

Non-child subjects $12-23$ months $=136$ The article did not list aOR $=89$

Articles included in systematic

review and meta-analysis $(\mathrm{n}=11)$

Figure 1. PRISMA flow diagram 
The initial search process gave 1826 article results, after the process of deleting published articles, there were 1495 articles with 236 of them fulfilling the requirements for further full text review. Full articles that fall within the exclusion criteria are articles that have been meta-analysis and duplicated.

Research related to the effect of maternal education and antenatal care on

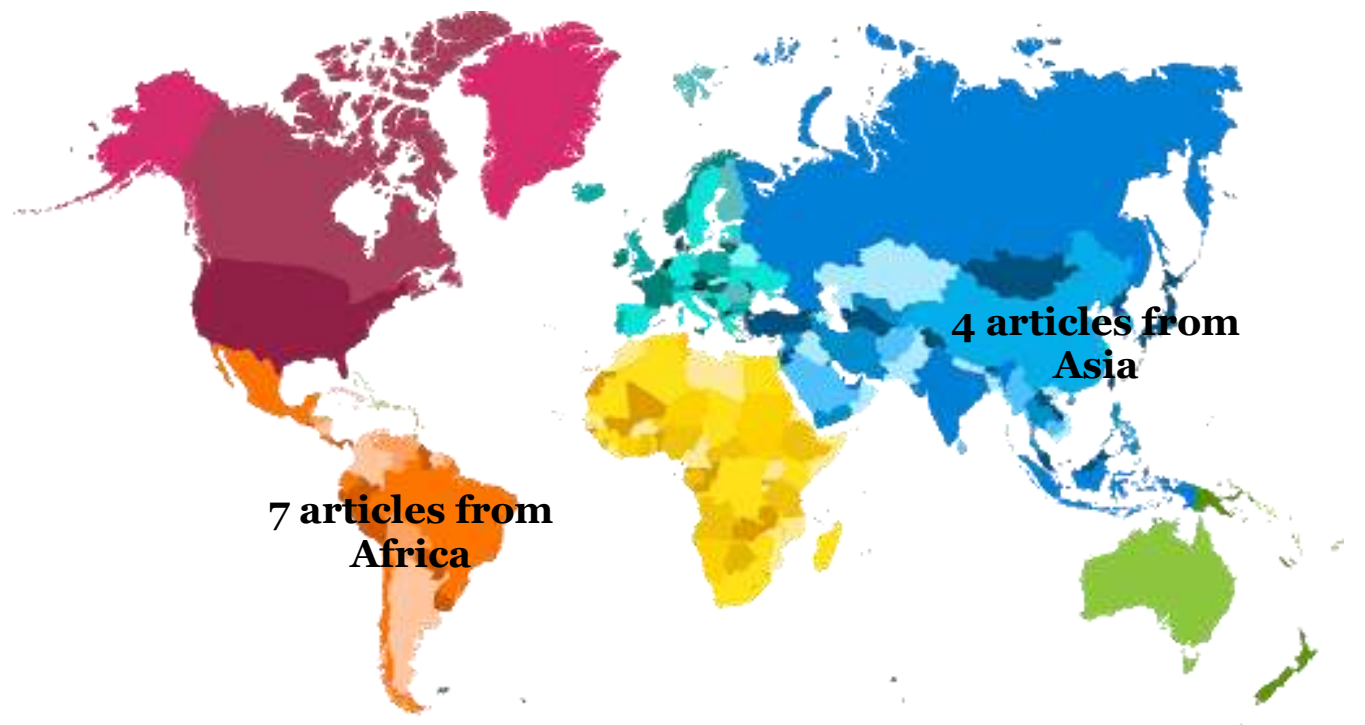

Figure 2. Map of research area on the effect of maternal education and antenatal care on complete basic immunization in children aged 12-23 months

\section{Research Quality Assessment}

An assessment of the quality of the research can be seen in Table 1 .

\section{Maternal Education}

There are 9 articles of observational study with cross sectional study design as a complete basic immunization in children aged 12-23 months contains 11 articles with the distribution of regions; 4 articles for the continent of Asia, and 7 articles for the continent of Africa. The findings of the articles analyzed based on the primary study can be seen in Figure 2 below.

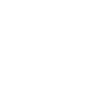


Farida et al./ Maternal Education, Antenatal Care, and Basic Immunization in Children

Table 1. Research Quality Assessment Table

\begin{tabular}{|c|c|c|c|c|c|c|c|c|c|c|c|c|c|}
\hline Publication & $\begin{array}{c}\text { Focus/ } \\
\text { research } \\
\text { question }\end{array}$ & $\begin{array}{c}\text { Study } \\
\text { design }\end{array}$ & $\begin{array}{c}\text { Selec- } \\
\text { tion of } \\
\text { subjects }\end{array}$ & $\begin{array}{c}\text { Sampling } \\
\text { mini- } \\
\text { mizes } \\
\text { selection } \\
\text { bias }\end{array}$ & $\begin{array}{c}\text { Sample } \\
\text { repre- } \\
\text { senta- } \\
\text { tive }\end{array}$ & $\begin{array}{c}\text { Sample } \\
\text { size } \\
\text { based on } \\
\text { pre study }\end{array}$ & $\begin{array}{c}\text { Achie- } \\
\text { vement } \\
\text { of res- } \\
\text { ponse }\end{array}$ & $\begin{array}{c}\text { Valid } \\
\text { and } \\
\text { reliable } \\
\text { instru- } \\
\text { ments }\end{array}$ & $\begin{array}{c}\text { Statistical } \\
\text { signi- } \\
\text { ficance } \\
\text { was } \\
\text { assessed }\end{array}$ & IC & $\begin{array}{c}\text { Con- } \\
\text { founding } \\
\text { that is } \\
\text { not taken } \\
\text { into } \\
\text { account }\end{array}$ & $\begin{array}{c}\text { Whether } \\
\text { the } \\
\text { results } \\
\text { can be } \\
\text { applied }\end{array}$ & Total \\
\hline $\begin{array}{l}\text { Legesse et al., } \\
2015\end{array}$ & 1 & 1 & 1 & 1 & 1 & 1 & 1 & 1 & 1 & 1 & 1 & 1 & 12 \\
\hline $\begin{array}{l}\text { Devasenapath } \\
\text { y et al., } 2016\end{array}$ & 1 & 1 & 1 & 1 & 1 & 1 & 1 & 1 & 1 & 1 & o & 1 & 11 \\
\hline $\begin{array}{l}\text { Adidire et al., } \\
2016\end{array}$ & 1 & 1 & 1 & 1 & 1 & 1 & 1 & 1 & 1 & 1 & 1 & 1 & 12 \\
\hline $\begin{array}{l}\text { Mbegue el al., } \\
2017\end{array}$ & 1 & 1 & 1 & 1 & 1 & 1 & 1 & 1 & 1 & 1 & 1 & 1 & 12 \\
\hline $\begin{array}{l}\text { Etana et al., } \\
2012\end{array}$ & 1 & 1 & 1 & 1 & 1 & 1 & 1 & 1 & 1 & 1 & 1 & 1 & 12 \\
\hline $\begin{array}{l}\text { Manuja et al., } \\
2018\end{array}$ & 1 & 1 & 1 & 1 & 1 & 1 & 1 & 1 & 1 & 1 & 1 & 1 & 12 \\
\hline $\begin{array}{l}\text { Noh Won et } \\
\text { al., } 2018\end{array}$ & 1 & 1 & 1 & 1 & 1 & 1 & 1 & 1 & 1 & 1 & 1 & 1 & 12 \\
\hline $\begin{array}{l}\text { Tesfaye et al., } \\
2018\end{array}$ & 1 & 1 & 1 & 1 & 1 & 1 & 1 & 1 & 1 & 1 & 1 & 1 & 12 \\
\hline $\begin{array}{l}\text { Girmay, et al., } \\
2019\end{array}$ & 1 & 1 & 1 & 1 & 1 & 1 & 1 & 1 & 1 & 1 & 1 & 1 & 12 \\
\hline $\begin{array}{l}\text { Pandey et al., } \\
2019\end{array}$ & 1 & 1 & 1 & 1 & 1 & 1 & 1 & 1 & 1 & 1 & o & 1 & 11 \\
\hline $\begin{array}{l}\text { Meconnen et } \\
\text { al., } 2020\end{array}$ & 1 & 1 & 1 & 1 & 1 & 1 & 1 & 1 & 1 & 1 & 1 & 1 & 12 \\
\hline
\end{tabular}


Farida et al./ Maternal Education, Antenatal Care, and Basic Immunization in Children

Table 2 Summary Source of maternal education for complete basic immunization for children aged 12-23 months in Asia and Africa

\begin{tabular}{|c|c|c|c|c|c|c|}
\hline Author, year & Title & Location & $\begin{array}{c}\text { Study } \\
\text { Design }\end{array}$ & $\underset{\text { size }}{\text { Sample }}$ & $\begin{array}{l}\text { Intervention (I) and } \\
\text { Comparison (C) }\end{array}$ & Outcome \\
\hline $\begin{array}{l}\text { Mbegue et al., } \\
2017\end{array}$ & $\begin{array}{l}\text { Determinants of complete immunization } \\
\text { among senegalese children aged } 12-23 \\
\text { months: evidence from the demographic } \\
\text { and health survey }\end{array}$ & $\begin{array}{l}\text { Senegal } \\
\text { (Africa) }\end{array}$ & $\begin{array}{l}\text { Cross- } \\
\text { sectional }\end{array}$ & 2.999 & $\begin{array}{l}\text { I: Highly educated mother } \\
\text { C: low educated mother }\end{array}$ & $\begin{array}{l}\text { Highly educated mothers can } \\
\text { increase the provision of complete } \\
\text { basic immunization to children }\end{array}$ \\
\hline $\begin{array}{l}\text { Girmay et al., } \\
2019\end{array}$ & $\begin{array}{l}\text { Full Immunization Coverage and } \\
\text { Associated Factors among Children 12-23 } \\
\text { Months Old in Hard-to-Reach Areas of } \\
\text { Ethiopia }\end{array}$ & $\begin{array}{l}\text { Ethiopia } \\
\text { (Africa) }\end{array}$ & $\begin{array}{l}\text { Cross } \\
\text { sectional }\end{array}$ & 623 & $\begin{array}{l}\text { I: Highly educated mother } \\
\text { C: low educated mother }\end{array}$ & $\begin{array}{l}\text { Highly educated mothers can } \\
\text { increase the provision of complete } \\
\text { basic immunization to children }\end{array}$ \\
\hline $\begin{array}{l}\text { Legesse et al., } \\
2015\end{array}$ & $\begin{array}{l}\text { An assessment of child immunization } \\
\text { coverage and its determinants in Sinana } \\
\text { District, Southeast Ethiopia }\end{array}$ & $\begin{array}{l}\text { Southeast } \\
\text { Ethiopia } \\
\text { (Africa) }\end{array}$ & $\begin{array}{l}\text { Cross- } \\
\text { sectional }\end{array}$ & 591 & $\begin{array}{l}\text { I: Highly educated mother } \\
\text { C: low educated mother }\end{array}$ & $\begin{array}{l}\text { Highly educated mothers can } \\
\text { increase the provision of complete } \\
\text { basic immunization to children }\end{array}$ \\
\hline $\begin{array}{l}\text { Meconnen et } \\
\text { al., } 2020\end{array}$ & $\begin{array}{l}\text { Timely completion of vaccination and its } \\
\text { determinants among children in } \\
\text { northwest, Ethiopia: a multilevel analysis }\end{array}$ & $\begin{array}{l}\text { Ethiopia } \\
\text { (Africa) }\end{array}$ & $\begin{array}{l}\text { Cross- } \\
\text { sectional }\end{array}$ & 774 & $\begin{array}{l}\text { I: Highly educated mother } \\
\text { C: low educated mother }\end{array}$ & $\begin{array}{l}\text { Highly educated mothers can } \\
\text { increase the provision of complete } \\
\text { basic immunization to children }\end{array}$ \\
\hline $\begin{array}{l}\text { Tesfaye et al., } \\
2018\end{array}$ & $\begin{array}{l}\text { Vaccination coverage and associated } \\
\text { factors among children aged } 12-23 \\
\text { months in Northwest Ethiopia }\end{array}$ & $\begin{array}{l}\text { North } \\
\text { west of } \\
\text { Ethiopia } \\
\text { (Africa) }\end{array}$ & $\begin{array}{l}\text { Cross- } \\
\text { sectional }\end{array}$ & 846 & $\begin{array}{l}\text { I: Highly educated mother } \\
\text { C: low educated mother }\end{array}$ & $\begin{array}{l}\text { Highly educated mothers can } \\
\text { increase the provision of complete } \\
\text { basic immunization to children }\end{array}$ \\
\hline $\begin{array}{l}\text { Noh Won et al., } \\
2018\end{array}$ & $\begin{array}{l}\text { Factors affecting complete and timely } \\
\text { childhood immunization coverage in } \\
\text { Sindh, Pakistan; A secondary analysis of } \\
\text { crosssectional survey data }\end{array}$ & $\begin{array}{l}\text { Pakistan } \\
\text { (Asia) }\end{array}$ & $\begin{array}{l}\text { Cross- } \\
\text { sectional }\end{array}$ & 2.252 & $\begin{array}{l}\text { I: Highly educated mother } \\
\text { C: low educated mother }\end{array}$ & $\begin{array}{l}\text { Highly educated mothers can } \\
\text { increase the provision of complete } \\
\text { basic immunization to children }\end{array}$ \\
\hline $\begin{array}{l}\text { Manuja et al., } \\
2018\end{array}$ & $\begin{array}{l}\text { A Cross Sectional Study on Vaccination } \\
\text { Coverage of Children in the Urban Slums } \\
\text { of Bangalore }\end{array}$ & $\begin{array}{l}\text { India } \\
\text { (Asia) }\end{array}$ & $\begin{array}{l}\text { Cross- } \\
\text { sectional }\end{array}$ & 210 & $\begin{array}{l}\text { I: Highly educated mother } \\
\text { C: low educated mother }\end{array}$ & $\begin{array}{l}\text { Highly educated mothers can } \\
\text { increase the provision of complete } \\
\text { basic immunization to children }\end{array}$ \\
\hline $\begin{array}{l}\text { Pandey et al., } \\
2019\end{array}$ & $\begin{array}{l}\text { Socio-demographic determinants of } \\
\text { childhood immunization coverage in rural } \\
\text { population of Bhojpur district of Bihar, } \\
\text { India }\end{array}$ & $\begin{array}{l}\text { India } \\
\text { (Asia) }\end{array}$ & $\begin{array}{l}\text { Cross- } \\
\text { sectional }\end{array}$ & 360 & $\begin{array}{l}\text { I: Highly educated mother } \\
\text { C: low educated mother }\end{array}$ & $\begin{array}{l}\text { Highly educated mothers can } \\
\text { increase the provision of complete } \\
\text { basic immunization to children }\end{array}$ \\
\hline $\begin{array}{l}\text { Devasenapathy } \\
\text { et al., } 2016\end{array}$ & $\begin{array}{l}\text { Determinants of childhood immunisation } \\
\text { coverage in urban poor settlements of } \\
\text { Delhi, India: a cross-sectional study }\end{array}$ & $\begin{array}{l}\text { India } \\
\text { (Asia) }\end{array}$ & $\begin{array}{l}\text { Cross- } \\
\text { sectional }\end{array}$ & 1343 & $\begin{array}{l}\text { I: Highly educated mother } \\
\text { C: low educated mother }\end{array}$ & $\begin{array}{l}\text { Highly educated mothers can } \\
\text { increase the provision of complete } \\
\text { basic immunization to children }\end{array}$ \\
\hline
\end{tabular}


Based on Table 2, a description of the primary research conducted by a metaanalysis of 9 articles, primary research was carried out in various locations, some from the Asian Continent ( 4 articles), and the African Continent ( 5 articles). The sample size conducted by the study averaged over 100 patients. Based on this research, it can be concluded that there is a significant effect of maternal education on providing complete basic immunization to children.

\section{a. Forest Plot}

Interpretation of the results of the primary research meta-analysis analysis of the effect of maternal education on giving complete basic immunization to children can be seen in the forest plot.

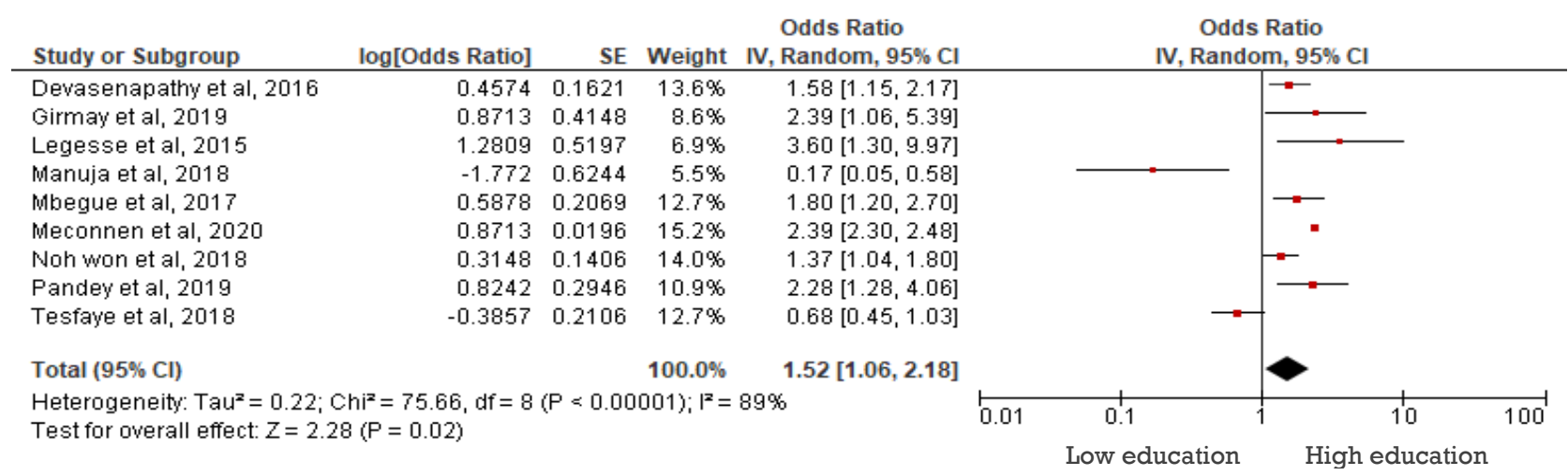

Figure 3. Forest Plot for maternal education on providing complete basic immunization to children

Based on the results of the analysis in Figure 3. It can be seen that 9 articles reported that maternal education was one of the factors that influenced the provision of complete basic immunization to children. Meanwhile, there was high heterogeneity between primary studies $\left(\mathrm{I}^{2}=89 \%\right.$; $\mathrm{p}<$ o.001). Thus the Random Effect Model is used. In the data analysis in the forest plot, high education level mothers were

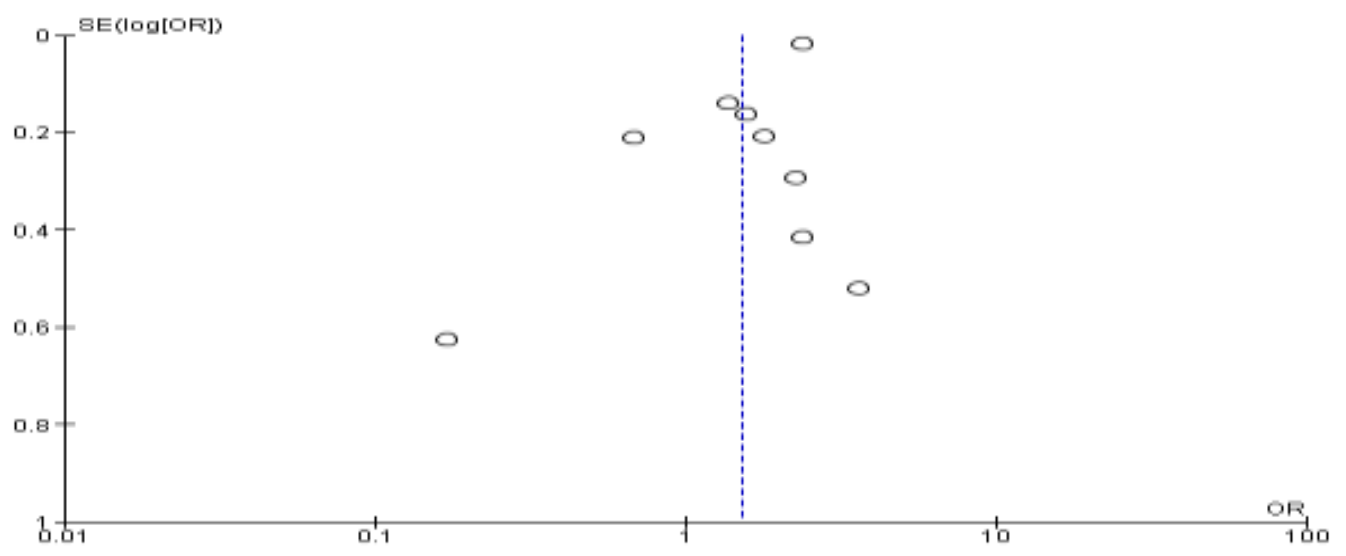

Figure 4. Funel Plot of the effect of maternal education on providing complete basic immunization to children in children aged 12-23 months
1.52 times more likely to complete vaccination of their children compared to mothers with low education which was statistically significant $(\mathrm{aOR}=1.52 ; 95 \%$ $\mathrm{CI}=1.06-2.18 ; \mathrm{p}=0.020$ ).

\section{b. Funnel Plot}

A funnel plot is a plot that depicts the estimated effect size of each study on its estimate of accuracy which is usually the standard error. 
Farida et al./ Maternal Education, Antenatal Care, and Basic Immunization in Children

Figure 4 shows a publication bias which is characterized by asymmetry of right and left plots where 3 plots tend to be on the left and 6 plots are on the right.

\section{Antenatal Care}

8 cross-sectional study showed the effect of antenatal care on providing complete basic immunization in children. An overview of the primary study reported in Table 3 .

Figure 5 showed that 8 articles reported that ANC affect the provision of complete immunization. There was high heterogeneity between primary studies $\left(\mathrm{I}^{2}=\right.$
69\%; $\mathrm{p}<0.001)$. Thus the Random Effect Model is used. In the data analysis in the forest plot, mothers who attended antenatal care 4 or more times during pregnancy were 2.62 times more likely to fully immunize their children $(\mathrm{aOR}=2.62 ; 95 \% \mathrm{CI}=$ 1.84-3.72; $\mathrm{p}=0.002$ ).

\section{a. Funnel Plot}

Funnel Plot is a plot that depicts the estimated effect size of each study on the estimate of its accuracy which is usually a standard error.

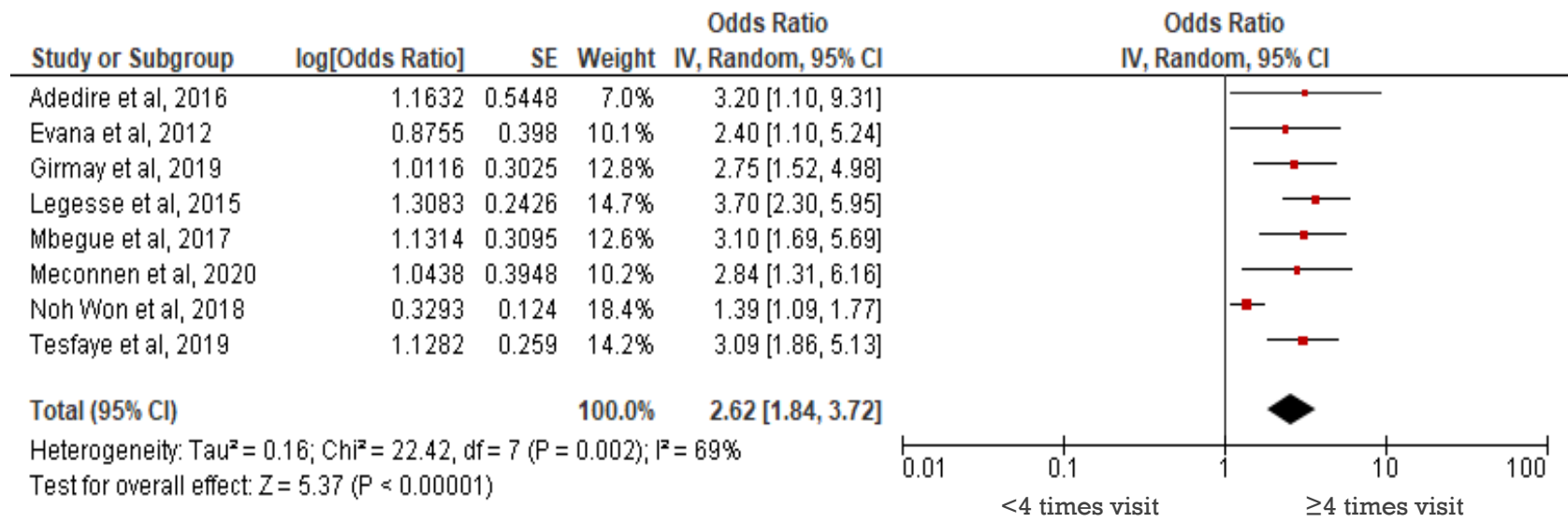

Figure 5. Forest Plot of antenatal care for giving complete basic immunization to children

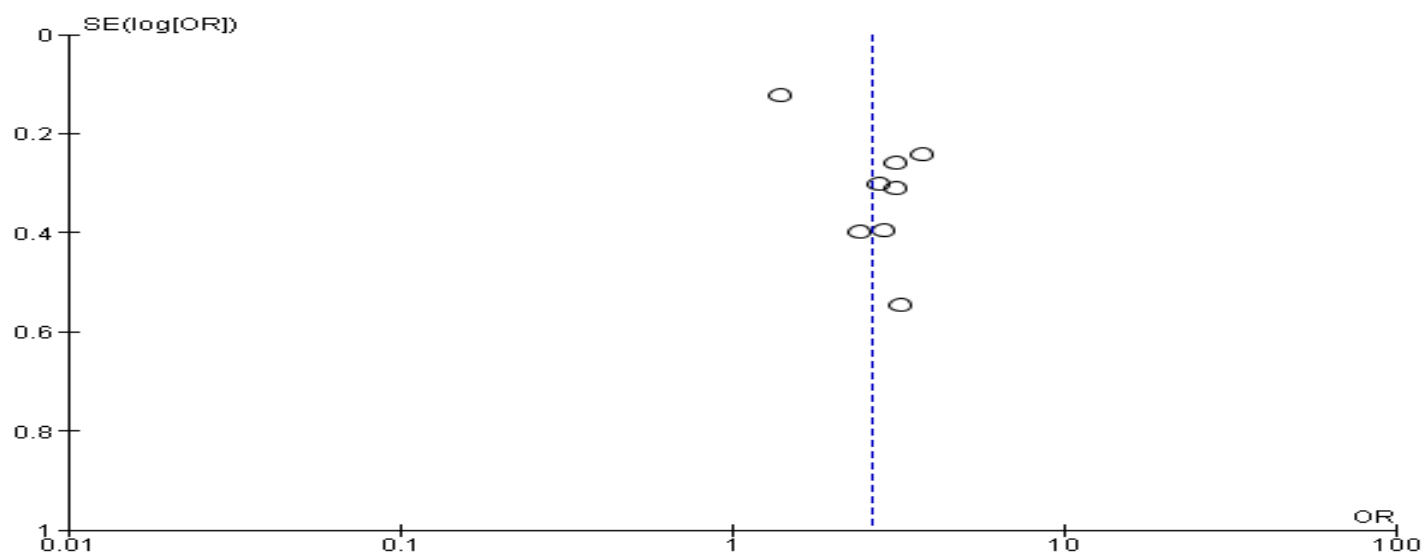

Figure 4.6 Funel Plot of the effect of antenatal care on providing complete basic immunization in children

Based on Figure 4.6, the funel plot of the effect of antenatal care on giving complete basic immunization to children shows a publication bias which is characterized by asymmetry of right and left plots where 2 plots tend to be on the left and 6 plots are on the right. 
Farida et al./ Maternal Education, Antenatal Care, and Basic Immunization in Children

Table 3. Summary Source of the effect of antenatal care on the provision of complete basic immunization in children aged 12-23 months

\begin{tabular}{|c|c|c|c|c|c|c|}
\hline $\begin{array}{l}\text { Author, } \\
\text { year }\end{array}$ & Title & Location & $\begin{array}{c}\text { Study } \\
\text { Design }\end{array}$ & $\begin{array}{l}\text { Sample } \\
\text { size }\end{array}$ & $\begin{array}{l}\text { Intervention (I) and } \\
\text { Comparison (C) }\end{array}$ & Outcome \\
\hline $\begin{array}{l}\text { Mbegue } \\
\text { et al., } \\
2017\end{array}$ & $\begin{array}{l}\text { Determinants of complete immunization } \\
\text { among Senegalese children aged } 12-23 \\
\text { months: evidence from the demographic } \\
\text { and health survey }\end{array}$ & $\begin{array}{l}\text { Senegal } \\
\text { (Africa) }\end{array}$ & $\begin{array}{l}\text { Cross- } \\
\text { sectional }\end{array}$ & 2,999 & $\begin{array}{l}\text { I: Antenatal care } \geq 4 \text { times } \\
\mathrm{C}: \text { Antenatal care }<4 \text { times }\end{array}$ & $\begin{array}{l}\text { Antenatal care of } 4 \text { times or } \\
\text { more can increase the complete } \\
\text { immunization of children. }\end{array}$ \\
\hline $\begin{array}{l}\text { Adedire et } \\
\text { al., } 2016\end{array}$ & $\begin{array}{l}\text { Immunisation coverage and its } \\
\text { determinants among children aged 12- } \\
23 \text { months in Atakumosa-west district, } \\
\text { Osun State Nigeria: a cross-sectional } \\
\text { study }\end{array}$ & $\begin{array}{l}\text { Nigeria } \\
\text { (Africa) }\end{array}$ & $\begin{array}{l}\text { Cross- } \\
\text { sectional }\end{array}$ & 750 & I: Antenatal care $\geq 4$ times & $\begin{array}{l}\text { Antenatal care of } 4 \text { times or } \\
\text { more can increase the complete } \\
\text { immunization of children. }\end{array}$ \\
\hline $\begin{array}{l}\text { Girmay et } \\
\text { al., } 2019\end{array}$ & $\begin{array}{l}\text { Full Immunization Coverage and } \\
\text { Associated Factors among Children 12- } \\
23 \text { Months Old in Hard-to-Reach Areas } \\
\text { of Ethiopia }\end{array}$ & $\begin{array}{l}\text { Ethiopia } \\
\text { (Africa) }\end{array}$ & Cross sectional & 623 & $\mathrm{C}:$ Antenatal care $<4$ times & $\begin{array}{l}\text { Antenatal care of } 4 \text { times or } \\
\text { more can increase the complete } \\
\text { immunization of children. }\end{array}$ \\
\hline $\begin{array}{l}\text { Legesse et } \\
\text { al., } 2015\end{array}$ & $\begin{array}{l}\text { An assessment of child immunization } \\
\text { coverage and its determinants in Sinana } \\
\text { District, Southeast Ethiopia }\end{array}$ & $\begin{array}{l}\text { Ethiopia } \\
\text { (Africa) }\end{array}$ & $\begin{array}{l}\text { Cross- } \\
\text { sectional }\end{array}$ & 591 & I: Antenatal care $\geq 4$ times & $\begin{array}{l}\text { Antenatal care of } 4 \text { times or } \\
\text { more can increase the complete } \\
\text { immunization of children. }\end{array}$ \\
\hline $\begin{array}{l}\text { Meconne } \\
\text { n et al., } \\
2020\end{array}$ & $\begin{array}{l}\text { Timely completion of vaccination and its } \\
\text { determinants among children in } \\
\text { northwest, Ethiopia: A multilevel } \\
\text { analysis }\end{array}$ & $\begin{array}{l}\text { Ethiopia } \\
\text { (Africa) }\end{array}$ & $\begin{array}{l}\text { Cross- } \\
\text { sectional }\end{array}$ & 774 & $\mathrm{C}:$ Antenatal care $<4$ times & $\begin{array}{l}\text { Antenatal care of } 4 \text { times or } \\
\text { more can increase the complete } \\
\text { immunization of children. }\end{array}$ \\
\hline $\begin{array}{l}\text { Tesfaye et } \\
\text { al., } 2018\end{array}$ & $\begin{array}{l}\text { Vaccination coverage and associated } \\
\text { factors among children aged } 12-23 \\
\text { months in Northwest Ethiopia }\end{array}$ & $\begin{array}{l}\text { Ethiopia } \\
\text { (Africa) }\end{array}$ & $\begin{array}{l}\text { Cross- } \\
\text { sectional }\end{array}$ & 846 & I: Antenatal care $\geq 4$ times & $\begin{array}{l}\text { Antenatal care of } 4 \text { times or } \\
\text { more can increase the complete } \\
\text { immunization of children. }\end{array}$ \\
\hline $\begin{array}{l}\text { Etana et } \\
\text { al., } 2012\end{array}$ & $\begin{array}{l}\text { Factor associated with complete } \\
\text { immunization coverage in children age } \\
12-23 \text { months in Ambo Woreda, Cental } \\
\text { Ethiopia }\end{array}$ & $\begin{array}{l}\text { Ethiopia } \\
\text { (Africa) }\end{array}$ & Cross sectional & 536 & $\mathrm{C}:$ Antenatal care $<4$ times & $\begin{array}{l}\text { Antenatal care of } 4 \text { times or } \\
\text { more can increase the complete } \\
\text { immunization of children. }\end{array}$ \\
\hline $\begin{array}{l}\text { Noh Won } \\
\text { et al., } \\
2018\end{array}$ & $\begin{array}{l}\text { Factors affecting complete and timely } \\
\text { childhood immunization coverage in } \\
\text { Sindh, Pakistan: A secondary analysis of } \\
\text { Cross sectional survey data }\end{array}$ & $\begin{array}{l}\text { Pakistan } \\
\text { (Asia) }\end{array}$ & $\begin{array}{l}\text { Cross- } \\
\text { sectional }\end{array}$ & 2,252 & I: Antenatal care $\geq 4$ times & $\begin{array}{l}\text { The number of } 4 \text { ANC visits was } \\
\text { significantly more likely for the } \\
\text { child to be fully immunized }\end{array}$ \\
\hline
\end{tabular}


Farida et al./ Maternal Education, Antenatal Care, and Basic Immunization in Children

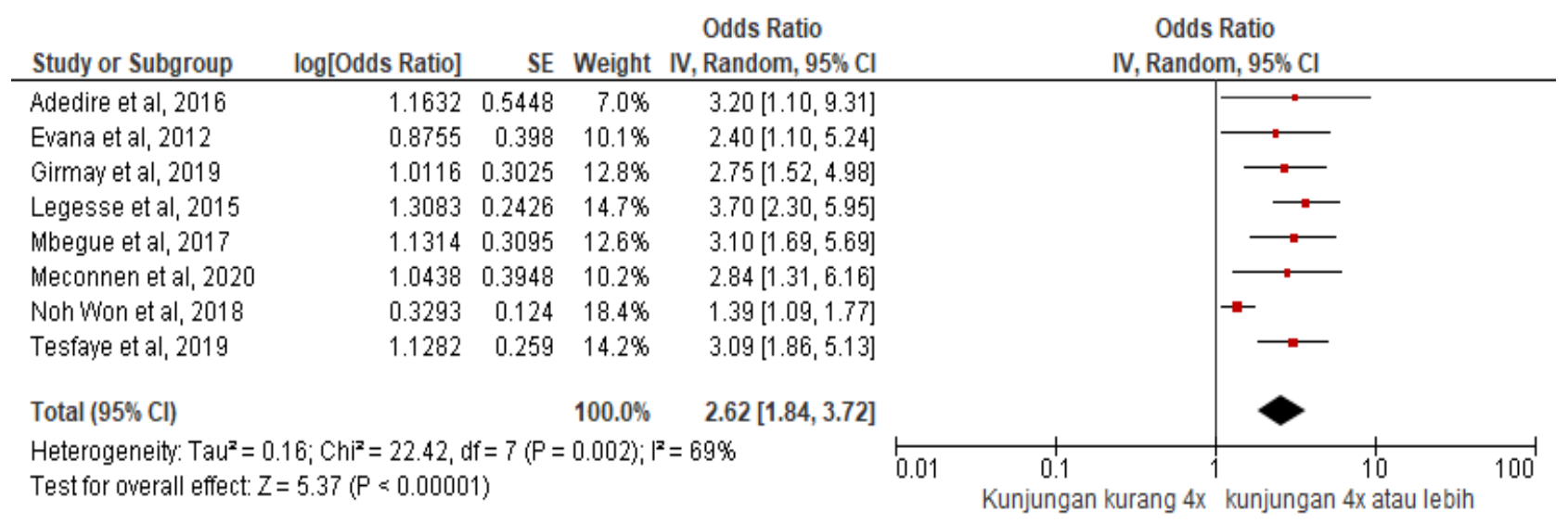

\section{Figure 5. Forest Plot of antenatal care for giving complete basic immunization to children}

Based on the analysis results in Figure 4.5. It can be seen that as many as 8 articles reported that antenatal care can affect the provision of complete immunization in children. Meanwhile, there was high heterogeneity between primary studies $\left(\mathrm{I}^{2}=\right.$ 69\%; p<0.001). Thus the Random Effect Model is used. In the data analysis in the forest plot, mothers who attended antenatal care 4 or more times during pregnancy

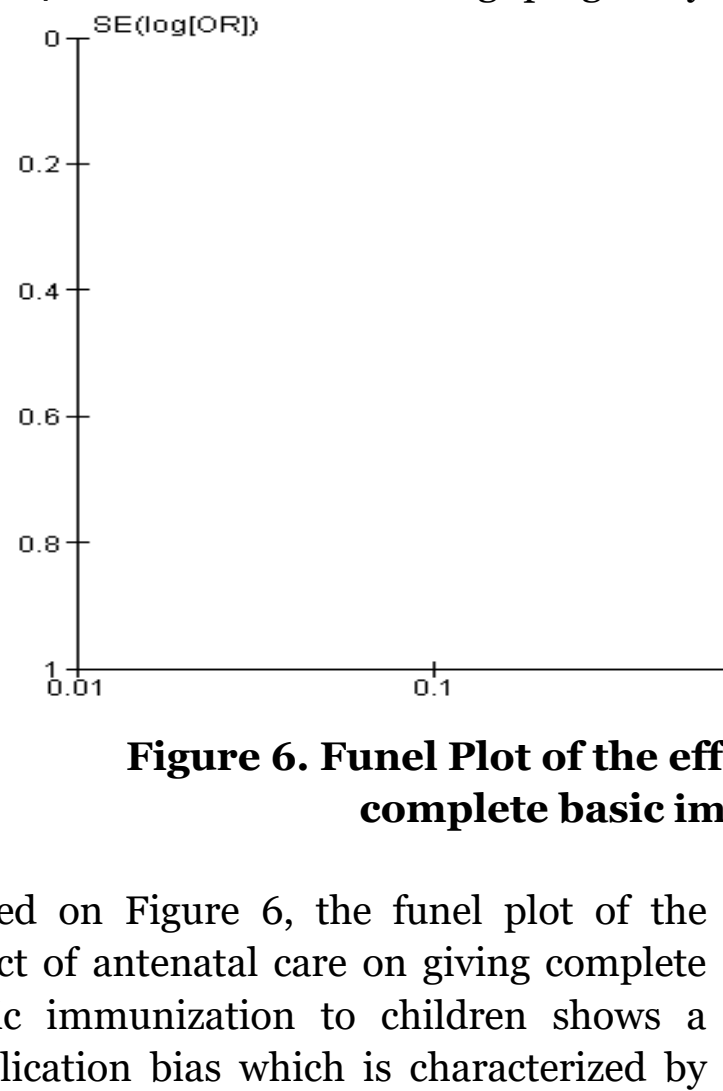

were 2.62 times more likely to fully immunize their children than those less than 4 times, which was statistically significant $(\mathrm{aOR}=2.62 ; 95 \% \mathrm{CI}=1.84-3.72 ; \mathrm{p}=0.002)$.

\section{b. Funnel Plot}

Funnel Plot is a plot that depicts the estimated effect size of each study on the estimate of its accuracy which is usually a standard error.

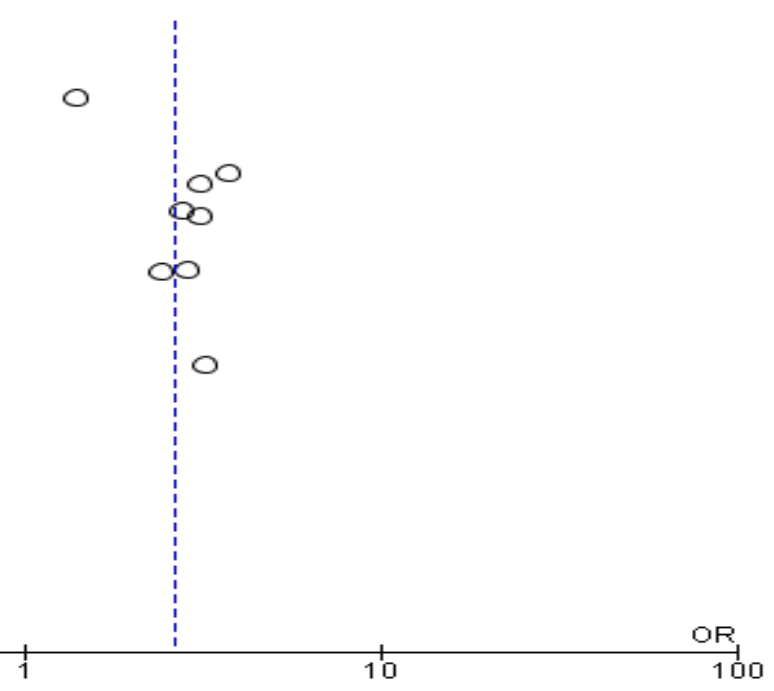




\section{DISCUSSION}

This systematic review and meta-analysis research raises the theme of the effect of maternal education and antenatal care on providing complete basic immunization to children aged 12-23 months. The number of relevant research published and accessible is still small and also has data access problems (data duplication) (Murti, 2018).

This systematic study and meta-analysis was conducted using a study that controlled for confounding factors which can be seen from the study inclusion requirements, namely multivariate analysis and the statistical result reported was the adjusted odd ratio (aOR).

Estimates of the effect of maternal education and antenatal care were processed using the RevMan 5.3 application with the generic inverse-variance method. This method is used to analyze data in the form of rate (rate), time-to-event (time-toevent), hazard ratio, ordinal scale, adjusted estimate, average difference. - average (difference of mean) or ratio of average (ratio of mean).

The results of the systematic study and meta-analysis are presented in the form of a forest plot and a funnel plot. The forest plot in the meta-analysis results shows visually the amount of variation (heterogeneity) (Murti, 2018). The funnel plot shows the relationship between the effect size of the study and the sample size of the various studies studied, which can be measured in a number of different ways (Murti, 2018). The funnel plot shows the effect size on the sample size, the funnel plot can be used to see the publication bias of the results of meta-analysis studies from combined primary studies. If the dots form an inverted funnel, with a wide base that narrows toward the top of the plot, and the points between the right and left are balanced, this indicates no publication bias.
Conversely, if the dots form an asymmetry between the right and the left, publication bias can be suspected.

\section{Mother education on giving complete basic immunization to children}

Based on the results of the forest plot, it shows that secondary or higher maternal education can increase the provision of complete basic immunization for children aged 12-23 months as much as 1.52 times compared to mothers with low education and statistically significant $(\mathrm{p}=0.020)$. The results of this study are in line with Mbegue et al. (2017) who stated that children aged 12-23 months who had highly educated mothers were more likely to be fully immunized $(\mathrm{aOR}=1.08 ; 95 \% \mathrm{CI}=1.20-2.48 ; \mathrm{p}=$ o.o01) compared to children with mothers with low education. An educated person will have knowledge that affects behavior, the higher a person's education, the better his behavior will be. Mothers with higher education levels can help mothers communicate with health workers efficiently and have a positive impact on vaccination through better understanding and acceptance of immunization knowledge.

A person's formal education will affect the ability to digest the information received. In terms of receiving messages, someone with basic education is usually slower than someone who has secondary or higher education. In addition, Holipah et al. (2018) stated that a mother with a higher education background is more likely to realize the importance of immunization.

Education is independently associated with complete immunization in children. Mothers with secondary education or above are more likely to have their children immunized than mothers with less education. Educated mothers are shown to be better at using the knowledge received from 
Farida et al./ Maternal Education, Antenatal Care, and Basic Immunization in Children

health workers during antenatal care (Awashti et al., 2015.)

\section{Antenatal care for giving complete basic immunization to children}

The results of the forest plot showed that mothers who attended 4 or more antenatal care visits were 2.62 times more likely to complete immunization on their children compared to mothers who attended antenatal care less than 4 times and it was statistically significant $(\mathrm{p}=0.002)$.

Mothers who attended antenatal care were less than 4 times less likely to complete basic immunization for their child compared to mothers who took antenatal care more than 4 times. In other words, those who attended the minimum standard of visits received positive benefits or completed immunization services (Efendi et al., 2019).

This is in line with previous research conducted by Nozaki et al. (2015) who stated that vaccination decision-making begins during pregnancy and that complete immunization coverage in children is associated with the presence of maternal antenatal care. Antenatal care programs generally provide information about child care including the schedule and importance of immunizations for children.

A limitation of this study was that the number of articles included in the metaanalysis was small according to the inclusion criteria. Language bias because in this study only articles published in English only ignored articles in other languages. Search bias because in this study the researcher only used 4 databases (PubMed, SpringerLink, Science Direct and Google Scholar) so that it ignored other search sources.

\section{AUTHOR CONTRIBUTION}

Farida is the main researcher who selects topics, explores and collects research data.
Vitri Widyaningsih played a role in analyzing the research data, and Bhisma Murti played a role in reviewing the document.

\section{CONFLICT OF INTEREST}

There is no conflict of interest in this study.

FUNDING AND SPONSORSHIP

This study is self-funded.

\section{ACKNOWLEDGEMENT}

We would like to thank the electronic database providers PubMed, Springer Link, ScienceDirect, and Google Scoolar

\section{REFERENCE}

Adedire EB, Ajayi I, Fawole OI, Ajunobi O, Kasasa S, Wassawa P, Nguku P (2016). Immunisation coverage and its determinants among children aged 12-23 months in Atakumosa-west district, Osun State Nigeria: A crosssectional study, BMC Public Health, 16(905), doi: 10.1186/s12889-0163531-x.

Adedokun ST, Uthman OA, Adekanbi VT, Wiysonge CS (2017). Incomplete childhood immunization in Nigeria: A multilevel analysis of individual and contextual factors, BMC Public Health, 17(236), doi: 10.1186/s12889017-4137-7.

Adenike OB, Adejumoko J, Olufunmi O, Ridwan O (2017). Maternal characteristics and immunization status of children in north central of Nigeria, Pan Afr Med J, 26, doi: 10.11604/pamj.2017.26.159.11530.

Adeloye D, Jacob W, Amuta AO, Ogundipe O, Mosaku O, gadanya MA, dan Oni G (2017). Coverage and determinants of childhood immunization in Nigeria: A systematic review and meta-analysis, Vaccine, Elsevier Ltd, 35(22): 28712881. doi: 10.1016/j.vaccine.2017.04.- 
Farida et al./ Maternal Education, Antenatal Care, and Basic Immunization in Children

034 .

Anulus A, Murti B, Prasetya H (2019). Risk factors of HIV among male military personnels: A meta analysis. J Health Promot Behav, 4(3): 178-188 doi: 10.26911/thejhpb.2019.04.03.03.

Asfaw AG, Koye DN, Demssie AF, Zeleke EG, Gelano YA (2016). Determinants of default to fully completion of immunization among children aged 12 to 23 months in south Ethiopia: Unmatched case-control study. Pan Afr Med J, 23, doi: 10.11604/pamj. 016.23.100.7879.

Awasthi A, Pandey CM, Singh U, Kumar S, Singh TB (2015). Maternal determinants of immunization status of children aged 12-23 months in urban slums of Varanasi, India. Clin Epidemiol Global Health. 3(3): 110-116. doi: 10.1016/j.cegh.2014.07.004.

Balogun SA, Yusuff HA, Yusuf KQ, AlShinqiti AM, Balogun $\mathrm{T}$, Tetty $\mathrm{P}$ (2017). Maternal education and child immunization: The mediating roles of maternal literacy and socioeconomic status. Pan Afr Med J. 26: 217. doi: 10.11604/pamj.2017.26.217.11856.

Borenstein M, Hedges LV, Higgins JPT, Rothstein HR (2009). Introduction to meta-analysis. first edit. West Sussex, United Kingdom: John Wiley \& Sons, Elsevier Ltd. Retrieved from https://www.meta-analysis.com/pages/-

book_introduction_to_metaanalysis.php.

Efendi F, Pradiptasiwi DR, Krisnana I, Kusumaningrum T, Kurniati A, Tri M Sampurna A, et al., (2019). Factors associated with complete immunizations coverage among Indonesian children aged 12-23 months. Children and Youth Services Review. 108: 104651 doi: 10.1016/j.childyouth. 2019.104651 .
Ekouevi D, Gbeasor FAG, Yaya I, Compaore WIZ, Boko A, Sewu E, Lacle A (2018). Incomplete immunization among children aged 12-23 months in Togo: A multilevel analysis of individual and contextual factors. BMC Public Health. 18(1): 952. doi: 10.1186/s12889-018-5881-z.

Ellis PD (2010). The essential guide to effect sizes statistical power, metaanalysis, and the interpretation of research results. New York: Cambridge University Press. Retrieved from: www.cambridge.org/9780521142465.

Erynda RF, Sulaeman ES, Pamungkasari EP (2020). Contextual effect of the integrated health post and other determinants on completeness of basic child immunization: A multilevel analysis evidence from Jember, East Java, Matern Child Health J, 5(2): 154-166. doi: https://doi.org/10.26911/ thejmch.2020.05.02.05.

Eshete A, Shewasinad S, Hailemeskel S (2020). Immunization coverage and its determinant factors among children aged 12-23 months in Ethiopia: a systematic review, and Meta- analysis of cross-sectional studies. BMC Pediatrics, 20(1): 283. https://doi.org/10.1186 /s12887-020-02163-0.

Feldstein LR, Mariat S, Dobo MG, Diailo MS, Conklin LM, Walace AS (2017). Global routine vaccination coverage, 2016. Morbidity and mortality weekly report. 66(45): 1252-1255. doi: 10.15585/mmwr.mm6645a3.

Forshaw J, Gerver SM, Gill M, Cooper E, Manikan L, Ward H (2017). The global effect of maternal education on complete childhood vaccination: A systematic review and meta-analysis. BMC Infect Dis. 17(1):801. doi: 10.1186/s12879-017-2890-y. 
Hailu S, Astatkie A, Johansson KA, Lindtjen B (2019). Low immunization coverage in Wonago district, southern Ethiopia: A community-based crosssectional study. PLoS ONE. 14(7): e0220144. doi: 10.1371/journal.pone.0220144 .

Holipah, Maharani A, Kuroda Y (2018). Determinants of immunization status among 12 to 23 month old children in Indonesia (2008 - 2013): a multilevel analysis, BMC Public Health. 18(1): 288. doi:/10.1186/s12889-018-51933 .

Kementerian Kesehatan RI (2015). Buku Ajar Imunisasi (Immunization Textbook). Edited by E. Mulati. Jakarta: Pusat Pendidikan dan Pelatihan Tenaga Kesehatan. Retrieved from http://www.pdpersi.co.id/pusdiknakes/.

Kementerian Kesehatan RI (2017). Peraturan Menteri kesehatan RI NO 12 Tahun 2017 Tentang Penyelenggaraan Imunisasi. Jakarta.

Lakew Y, Bekele A, Biadgilign S (2015). Factors influencing full immunization coverage among $12-23$ months of age children in Ethiopia: evidence from the national demographic and health survey in 2011. BMC Public Health. 15(728). doi: 10.1186/s12889015-2078-6.

Mbengue MAS, Sarr M, Faye A, Badiane O, Camara FBN, Mboun S, Dieye Tn, (2017). Determinants of complete immunization among Senegalese children aged $12-23$ months : Evidence from the demographic and health survey, BMC Public Health. 17(630). doi: 10.1186/s12889-017-4493-3.

Murti B (2018). Prinsip dan Metode Riset Epidemiologi (Epidemiological Research Principles and Methods). Edisi V. Surakarta: Bintang Fajar Offset.
Noh JW, Kim YM, Akram N, Yo KB, Park J, Cheon J, Kwon YD (2018). Factors affecting complete and timely childhood immunization coverage in Sindh, Pakistan; A secondary analysis of crosssectional survey data. PLoS ONE. 13(10): e0206766 doi: 10.1371/journal. pone.0206766.

Nozaki I, Hachiya M, Kitamura T (2019). Factors influencing basic vaccination coverage in Myanmar: Secondary analysis of 2015 Myanmar demographic and health survey data. BMC Public Health. 19, 242 (2019). doi: 10.1186/s12889-019-6548-0.

WHO (2019). Progress and Challenges with Achieving Universal Immunization Coverage, UNICEF. Retrieved from https://www.who.Int/immunization/monitoring surveillance/whoimmuniz.pdf.

WHO (2019a). Progress and Challenges with Achieving Universal Immunization Coverage, UNICEF. Retrieved from https://www.who.Int/ imunization/monitoringsurveillance/who-immuniz.pdf.

WHO (2019b) Recommended Routine Immunizations for Children. Retrieved from https://www.who.int/immunization/policy/Immunizati-on_routine.

WHO (2020). Immunization. Retrieved from https://www.who.int/topics/ immunization /en/.

WHO (2020a). Diphtheria tetanus toxoid and pertussis ( $\left.\mathrm{DTP}_{3}\right)$ immunization coverage among 1-year-olds (\%), World Health Organisation. Retrieved from http://apps.who.int/gho/indicatorregistry/App_Main.

WHO (2020c). Measles-containing-vaccine second-dose (MCV2) immunization coverage by the nationally recommended age, World Health Organi- 
Farida et al./ Maternal Education, Antenatal Care, and Basic Immunization in Children

zation. Retrieved from https://www.who.int/gho/immunization/measles2 /en/.

WHO (2020d). National programmes and systems, World Health Organisation. Retrieved from https://www.who.int/immunization/programmes_systems /en/.

WHO (2020e). SDGs Goal 3: Ensure healthy lives and promote well-being for all at all ages, UNITED NATIONS. Retrieved from https://www.un.org/ sustainabledevelopment/health/. 